\title{
From "Doing History" to Thinking Historically: Historical Consciousness across History and International Relations
}

\section{Introduction}

Whilst the origins of international relations (IR) as a discipline are deeply intertwined with historical reflection, the contemporary dominance of positivism in mainstream IR - often accused of being ahistorical - has nonetheless coincided with a renewed attention to the intellectual linkages between history and IR. ${ }^{1}$ This enduring disciplinary dialogue, which began with the so-called "second great debate" between behaviouralism and the historically-inspired English School, ${ }^{2}$ is not just a response to the growing trend in favour of post-positivist epistemology throughout the social sciences; it is also a consequence of the continuing use of historically rich case studies to construct and test IR theory. ${ }^{3}$ This dialogue has notably led to calls to close the gap - methodologically and epistemologically - between the two disciplines ${ }^{4}$ as well as helped specify the continuing divergence between the respective fields of inquiry in terms of the past being of interest in itself to historians as compared with the need to produce general theories within IR. ${ }^{5}$ However, this dialogue has proceeded with insufficient comparative reflection on how the disciplines consider what historical knowledge is useful for i.e. how they think historically or are historically conscious. The tendency in mainstream IR theory - as seen by the influence of Thucydides within classical realism - is to treat history as instructive, that is, as a repository of historical data from which lessons can be learned. This treatment has meant overlooking the fact that historiography has long been divided in terms of what is here termed "historical consciousness", referring to the way that historians view the writing of history as purposive without necessarily being instructive or lesson-based. This article seeks to highlight this division within history and explore whether or not this also exists within different traditions of thought in IR and, if so, what it reveals about the nature of the historical reflection underlying mainstream IR theory.

In other words, the article argues that dialogue between history and IR can be furthered beyond clarification and improvement of the different ways of "doing history" in $\mathrm{IR}^{6}$ that impact upon epistemology, causal explanations, and the methodology of theory-testing. Such dialogue over "doing history" has already amply demonstrated the benefit of overcoming the supposed nomothetic/idiographic disciplinary divide $;^{7}$ similarly, this literature has developed a powerful critique of ahistoricism in mainstream IR and rightly denounced the tendency to misuse history due to selection bias and limited interactions with primary sources. ${ }^{8}$ These preoccupations stem 
from the modern debate between positivist and post-positivist epistemologies that exists in $\operatorname{IR}^{9}$ but also in history, where historians clash over the writing of "correspondence" or "constructionist" histories. ${ }^{10}$ However, as this article shows, the debate over what historical knowledge is useful for - writing history as a political gambit rather than as a problem of methodology or epistemology - long predates this epistemological clash. It is for this reason that it is important to reconstruct how historiography has been divided in terms of what are called here different genres of historical consciousness.

At the same time, there is a tendency to consider that the most productive interdisciplinary dialogue that IR can achieve must take place outside mainstream IR theory, ${ }^{11}$ so that constructivism or the English School are better equipped to think critically about the nature of historical knowledge. It is certainly the case that constructivist theory, with its openness to multiple historical truths, is receptive to thinking about the historical record as something other than an independent store of knowledge about past events. ${ }^{12}$ The same is true for the English School, when seen in the light of William Bain's call to treat history as an idea or a construction of particular practitioners in the present. ${ }^{13}$ However, this article aims to demonstrate that different mainstream traditions of thought in IR theory also think historically, especially in terms of specific genres of historical consciousness not limited to viewing history as instructive. The traditions of mainstream IR considered here - realism and liberalism (including the latter's institutional variants) ${ }^{14}$ - can also be understood as paradigms, that is as

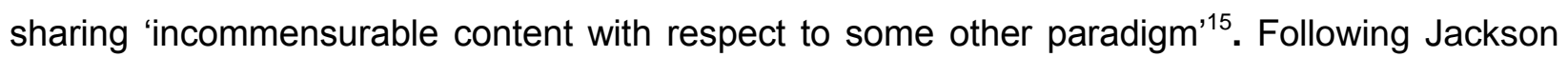
and Nexon, I separate these traditions around two axes or debates, namely: whether power politics can be tamed and whether anarchy is a fixed constraint on actors' interactions. Hence the analysis problematizes how traditions in IR that accept or reject anarchy, as well as power politics, are conscious of the connection between past, present, and future.

In particular, the article explores the extent to which both disciplines share similar genres of historical consciousness, looking specifically at whether history is understood as something other than instructive. What ultimately emerges from this comparison is the equally purposive or even political use of historical knowledge produced across both disciplines. Mainstream traditions of IR theory that argue power can be tamed, even if anarchy is still a fixed constraint, (such as democratic peace and neoliberal institutionalism) understand temporality by drawing lessons from history in a similar fashion to writers of history who treat the historical record as a teacher of experience. But just as there other are genres of historical consciousness in historical writing (history as representation, history as narrative), the realist tradition of thought that 
centres around the constraint of anarchy and the impossibility of taming power also draws different conclusions about the nature of temporality and hence the purpose of historical knowledge. The broad umbrella of realism (classical and structural realism) looks at history purposively and sees strict continuity in the lesson it provides about the fixed constraint of anarchy, which makes power the dominant feature of international order. However, when examined in closer detail the realist tradition can also be seen to view history as having its revenge on attempts to organize inter-state relations in the vain hope that power can be tamed if correct lessons about the past are learned. Further demonstrating that this tradition - unlike liberalism - manifests different genres of historical consciousness, the progressive strand of realism is also examined to show that it speculates that there might even be a potential to escape from history.

Uncovering this shared concern with producing historical knowledge for particular purposes based on historical consciousness - that is, how past, present and future are considered linked - can thus further the disciplinary dialogue beyond identifying common methodological and causal frameworks for grappling with historical data. A comparative examination of historical consciousness notably elucidates the way that despite attempts to distinguish social scientific theory-building from historical narratives or single case studies, both disciplines fundamentally rely on a purposive use of historical knowledge, based on a prior (often hidden) understanding of temporality. From this perspective, the supposed divide between idiographic history and nomothetic IR, or between chronicling and theory-building, masks the fact that both disciplines share not only the enterprise of reflecting upon the nature of temporality but also a concern with producing historical knowledge consistent with a particular and purposive understanding of history. Since both disciplines share this purposive understanding of historical knowledge, it becomes clear that the issue of how to "do history" in IR - i.e. how to adopt new methods or novel causal frameworks - needs to be complemented by a debate over how disciplines think historically. Consequently, as this article shows, there is a need for a more thorough engagement with a broader swathe of historiography as well as a recognition of the presence of different genres of historical consciousness across both disciplines.

\section{Engaging with Historiography and IR Theory through the Concept of Historical Consciousness}


What is striking about the existing exploration of how to do history in IR is the overwhelming reliance on contemporary historiography. Diplomatic history and its offshoot international history have been fundamental sources of inspiration for IR scholars seeking to pursue disciplinary dialogue. ${ }^{16}$ Historical sociology ${ }^{17}$ and postmodern history ${ }^{18}$ have also been integrated into this endeavour, further complicating epistemological and methodological interaction in a way that profits from the post-positivist turn in both disciplines. However, historical reflection long precedes the Methodenstreit [conflict over methods] of the nineteenth century, when the German historian Leopold von Ranke and his followers sought to establish an objective science of history. ${ }^{19}$ IR scholars feel at home in the surroundings of modern history precisely because von Ranke's movement opened up a long struggle over scientism and objectivist methodology analogous to that of the second (albeit contested) "great debate" in IR. ${ }^{20}$

Nevertheless, the article argues, it is worthwhile to excavate a larger swathe of historiography in order to analyse the extent to which the disciplines share a common way of thinking historically, i.e. an understanding of how past, present and future are connected. Consequently, this article first examines the evolution of the canon of Western historiography prior to the attempted positivist turn heralded by von Ranke: a complex and rich body of historical knowledge. It does so in order to bring to light the surprising degree to which the development of historical knowledge has been characterised by competing notions of temporality. The latter are analysed as genres of historical consciousness because the notion of consciousness - the negotiation between subject and experience - is fundamental to historical understanding for, as Kratochwil explains, history 'is the encounter with the self'. ${ }^{21}$ This negotiation gives rise to the phenomenon classified here as "historical consciousness": the student of history's awareness and understanding of the temporality of historical experience, the acknowledged consciousness of living in history. This is, therefore, a subjectivity or situatedness based on defining the nature of the relationship between past, present and future, which profoundly influences the production of historical knowledge. Indeed, historians' work always evinces a (largely hidden) purposive concern to produce historical knowledge for certain ends as determined by the genre of historical consciousness they subscribe to. In this sense historians are not just "doing history" (dependent on methods or causal frameworks) but also consciously thinking historically, based on the purposive use of historical knowledge for certain ends.

Scholars writing in the Western historical tradition have not shared a single notion of temporality and by implication there is no universal purposive project behind the writing of 
history in the pre-positivist era. Each genre of historical consciousness captures a different way of understanding the nature of temporality and what it means for the purpose of producing historical knowledge. The article identifies, in section 3, the presence of three different genres in the canonical work of European historians since antiquity: history as teacher, history as narrative, history as representation. It is these three genres of historical consciousness that are then contrasted with the way that different notions of temporality are invoked across two longstanding traditions of thought in IR: liberalism, with its rejection of power politics based on the belief in the taming effects of law and institutions, and realism, with its focus on the constraints of anarchy that make power the dominant factor of inter-state relations. The analysis in section 4 thus examines the extent to which these traditions display a conscious reflection about temporality - the emplotted relationship between past, present and future. Despite certain attempts to problematize temporality in IR theory, notably by critiquing the very notion of using history as a didactic resource, ${ }^{22}$ the use of a comparative, cross-disciplinary perspective that juxtaposes historical consciousness across both disciplines is a novel mode of inquiry. Theories that are in essence methodological and epistemological critiques of positivism, such as feminism, constructivism, or relationism, are not included, however, as while they can be applied to explain processes of change these critical approaches do not contain an inherent notion of temporality. The English School is also excluded from the analysis because its principal exponents do not share a common understanding of how to treat history when theorizing about international order. ${ }^{23}$

Analyzed according to their notion of temporality, the mainstream traditions of thought that differ over the constraint posed by anarchy and whether law or institutions can tame power, liberalism and realism, can be separated according to the genres of historical consciousness they espouse. Whereas liberalism in its different guises of democratic peace theory and neoliberal institutionalism adheres to the lessons of history genre, realism has a more complex relationship with history. Superficially, it manifests a sense that history has lessons, as both structural and classical realists point to an unbroken chronicle of power politics. However, both neorealism and classical realism rely on a less acknowledged genre, that of revenge of history, which suggests the immutable constraints of anarchy will shatter the best-laid projects of liberal institution-building. Yet the progressive tendency within classical realism, associated with the debate over the possibility of a world government, opens up the possibility of a third genre: escape from history, which identifies a fundamental caesura in the history of international relations that makes the present very much unlike the past, thereby implying that the future will 
look very different. The difference between these two traditions, as well as the variance within realism itself, further demonstrates the value of exploring understandings of temporality across the disciplines of history and international relations.

\section{Genres of Historical Consciousness in Historical Writing}

Historical writing has a hugely complex historiography - the latter is itself a significant sub-discipline of history that dates back at least to Lorenzo Valla's fifteenth-century exposure of the spurious nature of the donation of Constantine. Attempts to assign particular significance to different types of histories are controversial because of the absence of consensus over what (if anything) constitutes the canon of European historical writing. ${ }^{24}$ Not only are there multiple forms of historical writing, there are also myriad theories of historical causation since the historian's craft of using sources by definition implies 'a theory of possible history so that the sources might be brought to speak at all'. ${ }^{25}$ Similar issues arise when scholars of international relations have sought to draw on historical methods. However, the purpose of this article is not to inquire into theories about causation in history, a topic that has had a powerful influence on IR as discussed under the rubric of "doing history" above. Instead of focusing on debates over causation or the use of history, the overarching purpose in this section is to discuss the writing of history from the perspective of how notions of temporality (i.e. historical consciousness) have greatly influenced the type of history being written.

From this viewpoint, the article develops a taxonomy of three genres of historical consciousness that pervade the works of historians prior to von Ranke: history as teacher, history as narrative, history as representation. The existence of these different genres is largely overlooked, at least in light of IR's existing dialogue with history. This is because where IR scholars are conscious of the purposive dimension of historical writing it is overwhelmingly in terms of adapting the history as teacher genre for their own ends, leading to a neglect of how other genres of historical conscious treat the historical record. That is, the disciplinary dialogue in mainstream IR entails the use of history as a potential repository for lessons about how actors behave in international politics, mimicking the gambit of Thucydides' The Peloponnesian War in self-consciously treating the historical as an immortal or 'an everlasting possession' ${ }^{26}$

Although very much divided over how exactly to make use of this supposedly eternal resource, IR theory has from the outset been adept at drawing on the historical record to test hypotheses and construct explanatory frameworks. This trend runs the gamut from classical realists' use of Thucydides to explain pre-emptive conflict against hegemonic ambitions, 
attempts to prove the democratic peace thesis by creating a comprehensive database of the conflicts undertaken by democratic regimes, to constructivists' insistence on understanding actors' propensity to change their practices or norms, which necessarily entails exploring the historical representations, justifications, or narratives deployed. But despite the parallels evinced here with a particular kind of historical writing - history as teacher - disciplinary dialogue still needs to distinguish between and reflect upon different understandings of temporality within historical writing.

\section{History as Teacher}

This genre situates historical knowledge in terms of its pedagogical, moral and practical use for the present and future. This particular form of historical consciousness sees the past as containing a source of enduring inspiration and example (positive and negative) that needs to be recorded and transmitted to posterity in the hope of emulation and enhanced self-knowledge. Cicero rendered this pedagogical approach as historia magistra vitae - history as the teacher of life. Another canonical formulation of this approach to temporality can be found in Bede's prefatory dedication to his Historia ecclesiastica gentis Anglorum: 'if history relates good things of good men, the attentive hearer is excited to imitate that which is good'. ${ }^{27}$

The history as teacher genre of historical consciousness, which uses historical knowledge for the purpose of education and example, continues to this day to leave its mark on historical writing. Despite the positivist turn in history, the lives of great individuals continue to be a source of inspiration containing moral and political lessons of leadership and decision-making applicable today. ${ }^{28}$ This trope is not, though, confined to recounting the story of great lives for the edification and improvement of generations present and future. A more disembodied take on this form of historical consciousness examines the shifting fortunes of nation-states, as captured in Kennedy's Rise and Fall of the Great Powers (1989), ${ }^{29}$ with its aim of educating readers about the factors that determine the fortunes of great powers and which can illuminate America's predicament as sole superpower in the late twentieth century. Here again there is a classical origin to this approach of focusing on what the nations and regimes of the past can teach us about ineluctable cycles of success and failure in politics. ${ }^{30}$

This emphasis on the cyclicality of events or on the enduring need to learn moral and political lessons through historical example shows why the history as teacher genre of historical consciousness should not be confused with the philosophy of history tradition. The latter seeks not to find appropriate lessons for current circumstances but to interpret the purpose or 
teleology of historical development as manifested over a swathe of time. Perhaps most famously, this teleological interpretation was captured by Marx and Engels' declaration in The Communist Manifesto that 'the history of all hitherto existing society is the history of class struggle'. ${ }^{31}$ It has remained in common currency thanks to Fukuyama's ${ }^{32}$ claim that the demise of the Cold War was tantamount to the end of history given the supposedly unassailable triumph of liberal democratic values. This teleological tradition means looking at historical development 'from an absolute point beyond time', ${ }^{33}$ since it precludes considering the driving force behind historical development as itself a historically contingent interpretation. Hence for present purposes, philosophy of history is not treated as a genre of historical consciousness here even if it has been a guiding inspiration behind historical, especially Marxist, scholarship. ${ }^{34}$

\section{History as Narrative}

The purpose behind the history as teacher tradition is to render the - always useful past meaningful to aid in understanding the present and future predicament of individuals and states alike. By contrast, the aim of the history as narrative genre is principally to overcome the distance and separation between past and present whilst deliberately avoiding passing moral or political judgment. As suggested by the emphasis on narration, this form of historical writing tries to make the past accessible by recounting events in a story-like fashion that immerses the reader in the vivid minutiae of detail. ${ }^{35}$ The result is a form of historical consciousness that believes the stories of the past are, with the appropriate skill of retelling, comprehensible in themselves to the present. This means the historical record does not have to be framed as a self-conscious morality play and implies that the same events can be retold or re-used with a different narrative in the future as new information comes to light or a new perspective is added. Equally importantly, according to this form of historical consciousness, neither the present nor the future is considered to be at the mercy of how contemporaries appreciate and apply the significant lessons of history or else misconstrue or even misuse the symbols and stories of the

past. This genre thus uses historical knowledge to bring the past to light both without instrumentalising it to provide lessons and without claiming that the past is at the mercy of present preoccupations.

Thomas Carlyle is a supreme exemplar of this narrative genre, as the detail provided for his account of Marie-Antoinette's execution demonstrates:

At eleven, Marie-Antoinette was brought out. She had on an undress of piqué blanc: she was led to the place of execution, in the same manner as an ordinary criminal; bound, on a Cart; accompanied by a Constitutional Priest in Lay dress; escorted by numerous 
detachments of infantry and cavalry ... On reaching the Place de la Révolution, her looks turned towards the Jardin National, whilom Tuileries; her face at that moment gave signs of lively emotion. She mounted the Scaffold with courage enough; at a quarter past Twelve, her head fell; the Executioner showed it to the people, amid universal longcontinued cries of Vive la République. ${ }^{36}$

The eye-witness effect stands in sharp contrast with Edmund Burke's superimposition of an astringent moral reading of the fate of the same tragic figure in accordance with the history as teacher genre. For Burke - who conceived of history as a 'great volume unrolled for our instruction, ${ }^{37}$ - the death of the last French queen was indicative of something much broader and more repugnant than a moving tale of an unjust killing, namely that

Never, never more, shall we behold that generous loyalty to rank and sex, that proud submission, that dignified obedience, that subordination of the heart, which kept alive, even in servitude itself, the spirit of an exalted freedom! It is gone, that sensibility of principle, that chastity of honour, which felt a stain like a wound, which inspired courage whilst it mitigated ferocity, which ennobled whatever it touched, and under which vice itself lost half its evil, by losing all its grossness. ${ }^{38}$

Of course, the history as narrative genre does not preclude the ability to draw lessons from the many tragedies of fate and character littering the historical record, as Carlyle himself advocated in his lectures on heroes and hero-worship. ${ }^{39}$ However, the narrative tradition is based on a wager that the power of the story itself - the characters, the pathos, the denouement etc triumphs over any formulaic message about relevance or moral guidance as with Simon Schama's exhilarating retelling of the French Revolution. ${ }^{40}$ Indeed, the heyday of history as narrative, the early to mid-nineteenth century, provoked an academic reaction that placed a new disciplinary emphasis on rigour and scientific empiricism. This was the project of the German scholar Leopold von Ranke, who advocated the professionalization of the academic study of history based on primary documents, especially those recording the diplomatic relations of states. ${ }^{41}$ This attempted scientific revolution focused on determining history "as it really happened", thereby explicitly foreswearing reflection on the nature of temporality and an associated purposive understanding of historical knowledge. Dissatisfaction with this unachievable neutral, atemporal treatment of the historical record, has led the mainstream of academic history in the twentieth century to rediscover a third genre of historical consciousness simultaneously more comfortable and critical in its purposive use of history: history as representation.

History as Representation 
The genre defined here as history as representation shares the tendency of history as narrative to treat the historical record as a palimpsest, where different meanings and portrayals can be superimposed on the same events. But what matters for history as representation is not the power of the story or the craft of its telling. Rather, this way of thinking about history challenges the present's ability to represent the past by seeking to uncover the signs, symbols and even language that enable us to make sense of the past in its own terms as well as how these same elements have been used to represent a particular version of the past. This implies that the act of representing the past is in itself an inevitably political act whose genealogy needs to be laid bare. Hence the purpose behind this genre is to uncover precisely the genealogy underlying the contemporary use of the historical record.

In comparison with history as teacher and history as narrative, therefore, history as representation fundamentally problematizes the present's ability to understand the past - not in terms of the amount and quality of sources, as with von Ranke, but because of the changing as well as contested meaning and use of language, concepts and symbols. As a result, the ambition of this genre of historical consciousness is, unlike history as teacher, not to shape or even control the future. In this sense, it is an essentially critical rather than problem-solving approach to the study of history. That is, history as representation is critical about the contemporary misunderstanding and misuse of the past; if there are lessons to be learned from the past they are lessons about how easy it is to misrepresent the past.

An early classic in this genre is undoubtedly Alexis de Tocqueville's L'Ancien Régime et la Révolution (1856). Tocqueville's critical enterprise in this study was to debunk the prevailing assumption that the French Revolution overturned the entire structure of political authority in France by placing popular sovereignty in the stead of feudalism and monarchy. Indeed, this notion of a revolutionary break was very much at the heart of political debate throughout Tocqueville's lifetime, serving to polarize opinion between conservative reactionaries and defenders of an idealized republican movement. Yet this whole debate rested on a historical mistake, he argued. This was the result of an inability to understand the profoundly centralising tendencies of the last century of monarchical rule; a process that ironically provided a template for the revolutionaries who ostensibly sought to destroy the old order. Thus the claim that the revolution reshaped political authority by rooting out the old structures was precisely based, according to Tocqueville, on a misrepresentation of that old order. This error needed to be put right, for the sake of rescuing French politics from a self-destructive fallacy, by drawing on 
previously unexamined and unheralded features of relations between local and central authority as expressed in various provincial administrative archives.

To challenge misconceptions of the historical record, a high degree of magnification is needed; hence the recurring element of history as representation is a focus on the micro-level of historical actors and texts. A modern classic of this genre is Emmanuel Le Roy-Ladurie's study Montaillou. ${ }^{42}$ This work used archival inquisition documents about the Cathar heresy to reconstruct a thirty-year period in the life of a medieval village in south-west France to demonstrate - against the prevailing view of a benighted medievalism and intolerant Catholicism - the complexity of how its inhabitants understood and experienced the fundamental aspects of daily life, religious experience and family relations. The micro-level of magnification characteristic of much history as representation need not be confined to individuals ${ }^{43}$. Quentin Skinner's ${ }^{44}$ pioneering approach to the study of the history of political thought, based on a focus on language and speech acts contained in texts, thus follows history as representation by challenging earlier scholarship that detached (that is, misrepresented) political theorists from their historical context.

This broad overview of the three genres of historical consciousness located in historical writing has concentrated on explaining how history as teacher, history as narrative and history as representation understand the question of temporality - the relationship between past, present and future - and how these different ways of thinking historically determine the purpose of producing historical knowledge. The first genre seeks to uncover the lessons of the past for the sake of improving present and future conduct; the second aims to provide a narrative that resonates dramatically but apolitically with the present and which may be told differently in the future; the third and final genre questions the ability to understand, let alone use, the past for present purposes, preferring instead to show the difficulties of understanding the past in its own terms. Turning next to historical consciousness as it is present in IR, the following section uncovers the implicit presence of differing genres of historical consciousness as found in mainstream traditions of thought in IR: lessons of history, revenge of history, and the possibility of a speculative escape from history.

\section{Genres of Historical Consciousness in IR Theory and the Purposes behind Them}

Whereas the dominant paradigms of IR theory are normally separated in relation to how they perceive the importance of anarchy and the ability to tame power via rules or institutions, this section argues that the traditions of realism and liberalism can also be distinguished in 
terms of their understanding of temporality. In this way the genres of historical consciousness present in these traditions can thus be compared with those within historiography outlined above. In particular, the analysis claims that the existence of these genres reveals the inherently historical nature of IR theory - an enterprise that thinks historically by virtue of using historical knowledge purposively not just instructively.

\section{Lessons of History}

This genre of historical consciousness is present in the liberal tradition of IR theory, in particular in neoliberal institutionalism and democratic peace theory's claims that theorizing international relations requires, to varying degrees, the assimilation of certain historical lessons about inter-state relations. These theoretical frameworks thus treat the historical past as inherently instructive, sharing an ambition to engage with history in order to draw the correct lessons that help contribute to understanding the present and - to the extent that lessons can be applied in practice - designing the future.

What permeates neoliberal institutionalism is a concern with inter-state cooperation and how it can best be achieved so as to leave behind the pitfalls of anarchy. From this theoretical perspective, the history of institutions (supranational such as the UN, EU or WTO as well as their interaction with transnational actors such as NGOs or MNCs) reveals examples of why and under what conditions states cooperate. The purposive use of historical knowledge within this theoretical tradition is thus to provide positive lessons about successful cooperation yielding absolute or joint gains. Contrary to neorealist assumptions, neoliberal institutionalism shows that states are willing to forsake relative gains where the absolute gains are substantial and in multilateral cases that give rise to multiple equilibria. ${ }^{45}$ The historical record is there precisely to provide a data set to test 'the conditions under which institutions can have an impact and cooperation can occur'. ${ }^{46}$ In this context, the lesson of history is an inherently sanguine and policy-relevant one that 'institutions appear essential if states are to have any hope of sustained cooperation, and of reaping its benefits. ${ }^{47}$

Neoliberal institutionalism also provides an account of when international institutions fail to have the desired effect of (sufficiently) taming state selfishness and enabling stable cooperation. Here the lesson of history is that international institutions are most successful when they act as autonomous agents capable of changing state preferences, as in the EU example, rather than as merely oversight mechanisms for binding rules, for instance the UN. ${ }^{48}$ Moreover, the establishment of legal rules that give grounds for powerful transnational actors 
such as NGOs and firms to litigate in both supranational and domestic courts is shown to facilitate the legalization of inter-state cooperation, thereby restraining states' resort to unilateral measures and counter-measures. ${ }^{49}$

The ability to learn how to transcend violent inter-state conflict, at least within a subset of certain states, is also part and parcel of liberalism in the shape of democratic peace theory. This, albeit highly contested, way of theorising inter-state relations and the reasons behind animosity or belligerence is again based on taking the right lessons from the historical record. ${ }^{50}$ As with neoliberal institutionalism then, democratic peace theory is a theory that draws on the historical record to make and test claims about the nature of international politics, particularly processes of change. It is on this basis that they are treated as commensurate and comparable when it comes to their shared reliance on the same genre of historical consciousness.

In the conceptual language of Kenneth Waltz, democratic peace is a 'second image' theory that identifies various features of the domestic political system to explain the nature of the resulting peaceful international relations between democratic states. ${ }^{51}$ These features include constitutional checks on executive power, electoral checks on bellicose politicians, political transparency and openness that enable credible commitments to be made to other states as well as the shared value of resolving disputes through routinized dialogue and negotiation. Moreover, given their transparency and checking mechanisms, domestic democratic systems are more amenable to the creation of institutions for pacific inter-state cooperation that become a mutually reinforcing mechanism for international peace. ${ }^{52}$

Consequently, this theory of IR suggests that democratic states have succeeded in making an irreversible escape from a seeming intractable cyclical history of violent conflict. Peace via democracy is thus the key causal mechanism revealed by the history of inter-state relations - a claim that can already be found in Kant, ${ }^{53}$ who is traditionally taken as the intellectual progenitor of this theory. Indeed, for Kant, a state of "perpetual peace" - as opposed to an expanding separate peace between republics alone - is considered possible only after what he predicts will be "many unsuccessful attempts". As explained by Doyle, what this means is that a globally operating liberal peace is itself necessarily a product of historical experience and learning: 'right conceptions of the appropriate constitution, great and sad experience, and goodwill will have taught all the nations the lessons of peace'. ${ }^{54}$ Theorizing about history through the lens of democratic peace theory thus allows for the vindication of the particular institutional form, democracy, that can abolish the pathologies of inter-state competition, notably conflict 
between autocracies and between liberal states and illiberal opponents. At the same time, democratic peace theory suggests that historical knowledge can be used to strive for implementing the conditions that will allow citizens of different states to avoid war. It is no surprise then to find a leading exponent of democratic peace theory such as Doyle arguing, during the Cold War, that 'the violent lessons of war, and the experience of a partial peace [amongst democracies] are proof of the need for and the possibility of world peace'. ${ }^{55}$ There can be no more instructive use of history than this.

\section{Revenge of History}

At first glance, the realist tradition within IR theory appears to understand temporality according to the notion of history as teacher or lessons of history based on the longevity of the anarchic situation of international politics. That is, both classical and structural realists point to a historical continuity across their respective approaches. As espoused by John Mearsheimer, structural realism is well known for holding a 'grim picture of world politics' that is based on 'at least 1200 years of staying power'. ${ }^{56}$ Similarly, Sten Rynning claims that classical realism has 'a 2,500-year track record of pondering tragedy and criticizing modernity's blindness to its own capacity for destruction,57. However, the more deep-rooted genre of historical consciousness that manifests itself in the realist tradition is the tendency to conceive of the relationship between past, present, and future in terms of the "revenge of history" i.e. that state sovereignty under anarchy will always trump the best laid plans for constructing a rule based order. This is where realism can best be distinguished from liberalism in terms of temporality: it is a particular historical consciousness within realism that is used to justify scepticism about the liberal idea that anarchy can be transcended or that institutions and associated rules of order can tame the exercise of power.

Classical realism presents this element of revenge in an axiomatic form - or even an Augustinian sense of the impossibility of escaping from original $\sin ^{58}$ - although, as discussed below, there are some grounds for constructing a progressive version of this theoretical framework at odds with a revenge of history understanding of temporality. By contrast, neorealism realism couches its pessimistic conception of history in the idiom of positivist social science, using the notion of the anarchic structure of international politics to theorize the impossibility of escaping from contingent inter-state behaviour. The result is that realism is united in having a historically-based critique of liberal notions of improving inter-state relations.

Understood in terms of temporality, the structural realist worldview posits that the past will always be relevant and cannot be escaped, as captured in claims Mearsheimer made in 
1990 that the post-Cold War era would make Europe more conflict-prone and unstable than under bipolarity. ${ }^{59}$ In this way structural realism, alongside its critique of the causal claims of both democratic peace theory and neoliberal institutionalism, rejects the notion that history can be used didactically to improve inter-state relations. For structural realists such as Waltz or Mearsheimer, the absence of a hierarchical arrangement, akin to a world government, constraining inter-state behaviour means that neither domestic institutional structures nor international organizations can have a decisive and independent impact on how states behave. In this context, the revenge of history is such that policies based on contrary assumptions 'are bound to fail'; there is no meaningful scope for using historical learning to improve inter-state relations that can make the present different from the past. Hence structural realists' forwardlooking predictions are inherently pessimistic: 'misplaced reliance on institutional solutions is likely to lead to more failures in the future,.$^{60}$

In the specific case of European integration, the founder of neo-realism Kenneth Waltz argued that this instance of supranational innovation - a blueprint designed to pacify inter-state relations - was only viable because security concerns were delegated to NATO. ${ }^{61}$ More recently, Sebastian Rosato has tried to explain the anomaly of integration using an argument that explained why this process was a historical anomaly that ineluctable forces would undo. $\mathrm{He}$ posits that the extraordinary disparity in postwar power on the continent between Western Europe and the Soviet Union drove the countries of the former to take the extraordinary step of 'integrating their economies' in the 1950s. ${ }^{62}$ Cooperation in the economic sphere was, from this perspective, a long-term strategy intended to overcome a three-to-one power deficit in military terms. In doing so, West European states were creating the economic conditions necessary to provide the material and technological strength to resist potential Soviet aggression. 'The Europeans', Rosato argues, 'understood that they could compete effectively only if they built a single regional economy governed by a central authority'. ${ }^{63}$

It is precisely this logic that then leads to the claim that the contemporary absence of an external threat equates to the stagnation of integration, notably the failure of the project to endow the EU with a constitutional foundation. This controversial ${ }^{64}$ causal argument gives rise to a set of pessimistic conclusions about the revenge of inescapable historical drivers of interstate behaviour. Most importantly, it suggests that full-blown political and security integration is not possible in the absence of external compulsion. Consequently, an ideological commitment by elites or else a self-interested desire for more integration from national economic interests is insufficient to generate deeper integration. In fact, the "collapse of the Soviet Union has meant 
that the Europeans have not had a compelling geopolitical reason to preserve their economic community'.65

This conceit that history will have its revenge on the best-laid plans of policy planners is also a running thread through classical realism. As with Mearsheimer, European security is a privileged field for classical realists that share a revengeful vision of history precisely because of the political aspirations to construct institutional arrangements that can leave behind warfare and antagonism on that continent. However, E.H. Carr was a critic of federal designs in postwar Europe on the basis that it would re-create chauvinistic nationalism on a wider scale, something that only an admixture of national and functional international agencies could resolve. ${ }^{66}$ From this classical realist perspective, Carr argued, 'there would be little cause for congratulations in a division of the world into a small number of large multi-national units exercising control over vast territories and practicing in competition and conflict with one another a new imperialism which would be simply the old nationalism writ large and would almost certainly pave the way for more titanic and more devastating wars' ${ }^{67}$

A similar, pessimistic message about the futility of expecting institutions to solve problems inherent to mankind's social organization can be seen in Lindley-French's criticism of the EU's attempts to coordinate foreign policy. Comparing the Common Security and Defence Policy to earlier historical attempts to resolve continental inter-state relations, he notes that

today 'European leaders lack either the ingenuity or the clarity to know how to use [power]' ${ }^{68}$ In other words, the successful restraint of power is based on the existing of enlightened statesmen able to grasp the subtleties of the great game - as in the Concert of Europe - and not on the fetishization of institutions as ends in their own right. The historical consciousness of classical realism thus explains why the architecture of EU security today can be compared to the deadletter Locarno Treaty.

\section{The Speculative Possibility of an Escape from History}

Revenge of history found in varieties of realism, therefore, does not place history or historical methods on a pedestal for their own sake. Rather, the historical record is used purposively to demonstrate the futility of imagining a perfectibility based on assimilating lessons from the conduct of states or the operation of institutions they have designed together. The reasoning behind structural realism's rejection of the lessons of history genre of historical consciousness stems from the post-war intellectual project it derives from. That project, 
exemplified by Hans Morgenthau's attempt to develop a theory of power politics, was supposed to thwart the behaviouralist, scientific and inherently liberal turn in IR. Morgenthau and his acolytes believed the scientific turn in American political science was merely old wine in new bottles because it shared 'the same utopian drive that characterized the legalist vision of the interwar years'. ${ }^{69}$ This principle united Morgenthau, who mocked the idea 'that man is able to legislate at will, ${ }^{70}$ with Reinhald Niebuhr, who saw the new science of inter-state behaviour as predicated on the assumption that 'men [have] mastery over their historical fate'. ${ }^{71}$ Yet despite the Augustinian underpinnings of twentieth-century classical realism - which posits as a foundational historical constant that all humans, by extension, all states are morally flawed and prone to immoral acts - these authors also recognised another possible notion of temporality in place of revenge of history.

In a more speculative than explanatory guise, ${ }^{72}$ both Niebuhr and Morgenthau explored the possibility of a fundamental caesura in the history of international relations that makes the present very much unlike the past, in the process hypothesizing that the conditions were ripe for an unprecedented development in human history: a world government. From this perspective, the history of relations between states reveals the possibility of a novel need to establish an order that can triumph over the imperfections caused by the division of the globe into sovereign states. Rather than embracing the pure scepticism of thinking historically in terms of the revenge of history, Niebuhr - the most important mid-twentieth-century progressive realist during World War Two already saw the desirability of a global federal system. This belief was greatly reinforced by the development of the atomic bomb, with the nuclear revolution in fact making a world state a logical necessity in order to avoid the nuclear holocaust that a flawed humanity would most probably provoke. What Niebuhr and Morgenthau grappled with, therefore, was whether the very nature of international politics had changed, making the lessons or the revenge of the past equally inapplicable.

Importantly, any potential global escape from history was conceived of by these classical realists as the product of an evolutionary process and not couched in terms of a concrete institutional blueprint based on lessons of history. The new leviathan they envisioned existed only as a glimmer of hope that was realisable not by rational design but by potentially embracing the facts of thermonuclear warfare before it actually became a reality - hence the need to escape from this particular kind of historical possibility that threatened civilization itself. Speculation about a temporal sequence in which the future was separated out from the dynamics of past and present thus centred around the social and cultural basis for a world state, especially one that could avoid an authoritarian logic. For Niebuhr, the conditions for leaving 
behind existing history were vague and related to global social integration and cohesion. ${ }^{73}$ Similarly, Morgenthau, in the first edition of Politics Among Nations, used vague formulations to argue that 'If the world state is unattainable in our world, yet indispensable for the survival of that world, it is necessary to create the conditions under which it will not be impossible from the outset to establish a world state'. ${ }^{74}$ These "conditions" he went on to claim, relate to international diplomacy, an essentially practical field or craft rather than a cumulative empirical science in which the lessons of history can be applied. Hence this evolutionary understanding of the possibility for a fundamental caesura in international politics remained a fundamentally speculative, rather than an analytically profound, genre of historical consciousness.

\section{Conclusions}

This article stands squarely in the tradition of problematizing both the notion of historical understanding, as has occurred in the discipline of history itself, ${ }^{75}$ and the assumed disciplinary divide between history and IR. ${ }^{76}$ However, existing attempts to promote disciplinary dialogue between history and IR have underestimated the significance of thinking historically within and across the disciplines. The explanation offered here as to why this is the case is twofold: the narrow focus of IR scholars on epistemological debates within historiography that followed the attempted positivist turn and a focus on the history as teacher, and its analogue lessons of history, genre of historical consciousness. To engage with earlier historiographical debates concerning the purpose of historical knowledge production the article explored a broader swathe of the Western canon of historiography, to reveal how historians have been divided by their understanding of the nature of temporality.

It is precisely these competing notions of temporality, as argued in section 3 , that fundamentally affect historians' understanding of what the study of history is for, that is, the purpose behind linking together past, present, and future. By extension the presence of these or similar genres of historical consciousness needed to make sense of temporality has been overlooked when discussing the relationship between mainstream traditions of thought in IR and history. Yet as was shown in section 4, different genres of historical consciousness are present across various strands of mainstream IR theory. Those identified in this article - lessons of history, revenge of history, and a more speculative notion of an escape from history - are not the same as those present in the discipline of history, thereby illustrating a divide over how temporality is understood. Nevertheless, the presence of different genres of historical 
consciousness across both disciplines corresponds with their different purposive enterprises, further revealing the artificiality of the nomothetic/idiographic divide by showing that history is not simply the study of the past for its own sake. ${ }^{77}$

The shift advocated here to move away from "doing history" to thinking historically is thus not intended to provide methodological pointers but rather to explore what still separates IR and history when it comes to thinking historically. Distinctions in how the disciplines think historically point to different ways of thinking historically that can also potentially inspire intellectual cross-pollination. History as teacher, of course, bears a striking resemblance to the lessons of history genre that claims historical understanding is needed, if not to improve the present and future, then at least to avoid mistakes that could make things worse. But this instructive approach to history is not the only way that IR theory can think historically, just as historiography has concerns beyond moral or political improvement. Significantly, revenge of history does not seem to have an equivalent in the historical profession, just as history as narrative does not have an analogue in mainstream paradigms of IR theory. It is an open question as to how far IR theory can think historically along the lines of history as representation, that is, with an understanding of temporality that problematizes the ability to access the past. This way of thinking poses an inherent challenge to democratic peace theory and neoliberal institutionalism as they assume the commensurability of past and present, suggesting perhaps that this genre of historical consciousness has a more natural application outside the mainstream, with Herbert Butterfield's treatment of the historical record as incomplete, permitting only interim knowledge, providing a clue as to the possibilities therein. ${ }^{78}$

Furthermore, the contrast between liberalism and realism showed the complexity of how temporality is understood within the latter paradigm and provides another conceptual starting point for distinguishing between these two "isms". The existence of different genres of historical consciousness within realism can also function to capture the split between realists that lies not in the origin of anarchy itself - human nature or exogenous structure - but in how realists think historically. While classical and structural realists might agree that history is instructive in a negative fashion that confounds hopes of simple lesson-learning, this article has shown that the former envisage not just a revenge of history but a potential escape from it. In this context, realism appears torn between two different ways of critiquing the assumption that historical knowledge provides an instructive toolkit that allows for improved inter-state relations.

What emerges, therefore, from this juxtaposition of genres of historical consciousness across the two disciplines is the extent to which mainstream paradigms of IR theory are predisposed to thinking historically. Not only is IR dependent on historical data - however 
problematic its use may be in practice - provided by history; liberalism and realism are also fundamentally engaged in reflecting on the nature of temporality. Historical consciousness thus runs through both IR theory and historiography, albeit in different ways. More fundamentally, the analysis revealed the inherently purposive use of historical knowledge across both disciplines. However, this conclusion further implies that productive disciplinary dialogue needs to look beyond the question of "doing history" to consider also how to think historically in terms of different understandings of temporality. In particular, as shown by an analysis of the differing presence of historical consciousness across both history and IR, a comparative examination of understandings of temporality - requiring engagement with a broad swathe of historiography is a promising gambit for exploring this dimension of the disciplinary dialogue.

\footnotetext{
1 These linkages have been explored by, inter alios, T. W. Smith, History and International Relations (London: Routledge, 1999); C. Elman and M. F. Elman (eds.), Bridges and Boundaries: Historians, Political Scientists, and the Study of International Relations (Cambridge, MA: MIT Press, 2001); D. Puchala, Theory and History in International Relations (London: Routledge, 2003); Y. Ferguson and R. W. Mansbach (2008) 'Polities Past and Present', Millennium: Journal of International Studies, 37(2), 2008, pp. 365-79; for an attempt to bring historicity into IR see N. Vaughan-Williams, 'International relations and the "Problem of History"', Millennium: Journal of International Studies, 34( 1), 2005, pp. 11536.

${ }^{2}$ H. Bull, 'International Relations Theory: The Case for a Classical Approach', World Politics, 18 (April), 1966, pp. 361-77; cf. Stephen Hobden, 'Historical Sociology: back to the future of international relations?', in .S. Hobden and J. Hobson (eds), Historical Sociology and International Relations, (Cambridge: Cambridge University Press, 2002), pp. 42-62, and F. Kratochwil, 'History, Action and Identity: Revisiting the "Second" Great Debate and Assessing its Importance for Social Theory', European Journal of International Relations, 12(1), 2006, pp. 5-29.

${ }^{3}$ Recent examples of historically-rich case studies span the theoretical spectrum and include positivist as well as non-positivist epistemological approaches. See for instance G. J. Ikenberry, After Victory: Institutions, Strategic Restraint and the Rebuilding of Order after Major Wars (Princeton: Princeton University Press, 2000); J. Mearsheimer, The Tragedy of Great Power Politics (New York: Norton: 2001); D. Deudney, Bounding Power: Republican Security Theory from the Polis to the Global Village (Princeton: Princeton University Press, 2007); D. Nexon, The Struggle for Power in Early Modern Europe: Religious Conflict, Dynastic Empires, and International Change (Princeton: Princeton University Press, 2009).

G. Lawson, 'The Eternal Divide? History and International Relations', European Journal of International Relations 18(2), 2012, pp. 203-26; Elman and Elman (eds.) Bridges and Boundaries. See also their article 'The Role of History in International Relations', Millennium: Journal of International Studies, 37(2), 2008, pp. 357-64.

${ }^{5}$ Elman and Elman, Bridges and Boundaries, 7.

${ }^{6}$ On this problem see J. M. Hobson and G. Lawson 'What is History in International Relations?', Millennium: Journal of International Studies, 37(2), 2008, pp. 415-35.

${ }^{7}$ Elman and Elman, 'The Role of History'.

8 Much of this criticism is reserved for realist scholars' historiographical misappropriations. See F. Kratochwil and R. Hall, 'Medieval Tales: Neorealist "Science" and the Abuse of History', International Organization, 47(3), 1993, pp. 479-92 and P. Shroeder, 'Historical Reality vs. Neo-Realist Theory', International Security, 19(2), 1994, pp. 108-48. On the problem of the limitations encountered by nonhistorians when interpreting sources see R. H. Lieshout et al., 'De Gaulle, Moravcsik, and the Choice for Europe: Soft Sources, Weak Evidence', Journal of Cold War Studies, 6(4), 2004, pp. 89-139; cf. I. Lustick, 'History, Historiography and Political Science', American Political Science Review, 90(3), 1996, pp. 605-18.
} 
${ }^{9}$ Jonathan B. Isacoff, 'On the Historical Imagination of International Relations: The Case for a Deweyan Reconstruction', Millennium: Journal of International Studies, 31(3), 2002, pp. 603-26.

${ }^{10}$ Lawson, 'The Eternal Divide?'.

${ }^{11}$ Caroline Kennedy-Pipe, 'International History and International Relations Theory: A Dialogue Beyond the Cold War', International Affairs, 76(4), 2000, pp. 741-54.

${ }^{12}$ Christian Reus-Smit, 'Reading History through Constructivist Eyes', Millennium: Journal of International Studies, 37(2), pp. 395-414.

${ }^{13}$ William Bain, 'Are There Any Lessons of History? The English School and the Activity of Being a Historian', International Politics, 44, pp. 513-530.

${ }^{14}$ These two "isms" are the dominant the field in the US as demonstrated by S. Peterson, M. J. Tierney, and D. Maliniak, Teaching and Research Practices, Views on the Discipline, and Policy Attitudes of International Relations Faculty at US Colleges and Universities (Williamsburg, VA: College of William and Mary, 2005).

${ }^{15}$ P. T. Jackson and D. Nexon, 'Paradigmatic Faults in International Relations Theory', International Studies Quarterly, 53(4), 2009, pp. 907-930, quotation p. 907.

${ }_{17}^{16}$ Elman and Elman, 'The Role of History'.

${ }^{17}$ Hobden and J. Hobson, Historical Sociology.

${ }^{18}$ Vaughan-Williams, 'International relations and the "Problem of History"'.

${ }^{19}$ Von Ranke's enterprise was an attempt to define historical writing as the exact exposition of wie es eigentlich gewesen ist [how it actually happened/ the past as it once was]. On this subject see G. Iggers, The German Conception of History: The National Tradition of Historical Thought from Herder to the Present (Middletown, CT: Wesleyan University Press, 1968.

${ }^{20}$ On the debate in history see P. Novick, That Noble Dream: The Objectivity Question and the American Historical Profession (Cambridge: Cambridge University Press, 1988).

${ }^{21}$ Kratochwil, 'History, Action and Identity', p. 15.

${ }^{22}$ Bain, 'Are There Any Lessons of History?'

${ }^{23}$ Bain, 'Are There Any Lessons of History?' Cf. A. Linklater,. and H. Suganami, The English School of International Relations: A Contemporary Reassessment (Cambridge: Cambridge University Press, 2006).

${ }^{24}$ See D.R. Kelley Versions of History from Antiquity to the Enlightenment (New Haven: Yale University Press, 1991).

${ }^{25}$ R. Koselleck, Futures Past: on the Semantics of Historical Time (New York: Columbia University Press, 2004), p. 151.

${ }^{26}$ Thucydides, History of the Peloponnesian War, trans. W. Smith (Philadelphia: Edward Earles, 1819), vol. 1, p. 17.

${ }^{27}$ Bede, The History of the English Church and People (New York: Barnes and Noble, 2005), p. 1.

28 See for instance J. McPherson, Lincoln and the Second American Revolution (Oxford: Oxford University Press, 1990).

${ }^{29}$ P. Kennedy, The Rise and Fall of the Great Powers: Economic Change and Military Conflict, 15002000 (New York: Vintage, 1989).

30 The ancient tradition begins with Polybius, The Histories of Polybius, trans. E. S. Shuckburgh (Bloomington: Indiana University Press, 1962).

${ }^{31}$ K. Marx and F. Engels, The Communist Manifesto, trans. S. Moore (London: Verso, 1998), p. 34.

${ }^{32}$ F. Fukayama, The End of History and the Last Man (New York, NY: The Free Press, 1992).

${ }^{33}$ Kratochwil, 'History, Action and Identity', 10.

${ }^{34}$ See C. Hill, The English Revolution 1640 (London: Lawrence and Wishart, 1940).

${ }^{35}$ Here the notion of history as narrative does not therefore entail treating narrative as a species of causal explanation as Suganami has advocated in IR. See H. Suganami, 'Narrative Explanation and International Relations: Back to Basics', Millennium: Journal of International Studies, 37(2), 2008, pp. 327-56.

${ }^{36}$ T. Carlyle, The French Revolution: A History in Three Volumes (London: James Fraser, 1837), vol. 3, p. 273.

37 E. Burke, Select Works of Edmund Burke. A New Imprint of the Payne Edition. Foreword and Biographical Note by Francis Canavan (Indianapolis: Liberty Fund, 1999), vol. 2, p. 165. 
${ }^{38}$ E. Burke, Select Works of Edmund Burke, p. 89.

39 T. Carlyle, On Heroes, Hero-Worship, and the Heroic in History (London: James Fraser, 1841).

${ }^{40} \mathrm{~S}$. Schama, Citizens : A Chronicle of the French Revolution (New York : Alfred A. Knopf, 1989).

${ }^{41}$ On the legacy of von Ranke's objectivist project see P. Novick, That Noble Dream.

${ }^{42}$ E. Le Roy-Ladurie, Montaillou, village occitan de 1294 à1324 (Paris: Gallimard, 1975).

${ }^{43}$ See notably P. Maier, American Scripture: Making the Declaration of Independence (New York: Alfred A. Knopf, 1997).

44 See most importantly Q. Skinner, The Foundations of Modern Political Thought (Cambridge: Cambridge University Press, 1978), 2 vols.

${ }^{45}$ D. Snidal, 'Relative Gains and the Pattern of International Cooperation', American Political Science Review, 85(3), 1991, 701-26.

${ }^{46}$ R. Keohane and L. Martin, 'The Promise of Institutionalist Theory', International Security, 20(1), 1995, pp. 39-51, at p. 42.

${ }^{47}$ Keohane and Martin, 'The Promise of Institutionalist Theory', p. 50.

${ }^{48}$ R. Jervis, 'Realism, Neoliberalism and Cooperation: Understanding the Debate', International Security 24(1),1999, pp. 42-63.

${ }^{49}$ K. Alter, 'Who Are the Masters of the Treaty'?: European Governments and the European Court of Justice." International Organization, 52(1), 1998, pp. 121-47.

${ }^{50}$ For an overview of this congested and contested theoretical field see M. Doyle, (1983) 'Kant, Liberal Legacies and Foreign Affairs', Philosophy and Public Affairs, 12(1/2), 1983, pp. 205-35, 323-53; C. Lipson, Reliable Partners: How Democracies Have Made a Separate Peace (Chicago: University of Chicago Press, 2003); G. Levy and R. Razin, 'It Takes Two: an Explanation for the Democratic Peace', Journal of the European Economic Association, 2(1), 2004, pp. 1-29.

${ }^{51}$ Kenneth Waltz, Man, the State, and War (New York: Columbia University Press, 1959).

52 Lipson, Reliable Partners.

53 I. Kant, To Perpetual Peace: A Philosophical Sketch, trans. T. Humphrey (Indianapolis: Hackett, 2003).

${ }^{54}$ Doyle, 'Liberal Legacies', p. 226.

${ }^{55}$ Michael Doyle, 'Liberalism and World Politics', American Political Science Review, 80(4), 1986, pp.

1151-69, quotation p. 1163.

${ }^{56} \mathrm{~J}$. Mearsheimer, 'The False Promise of International Institutions', International Security, 19(3), 1995, pp. 5-49, quotation p. 9.

${ }^{57}$ S. Rynning, 'Realism and the Common Security and Defence Policy', Journal of Common Market Studies, 49(1), 2011, pp. 23-42, at p. 35.

${ }^{58}$ Most prominent in the work of Reinhold Niebuhr. See H. A. Warren, Theologians of a New World Order: Reinhold Niebuhr and the Christian Realists (Oxford: Oxford University Press, 1997).

$59 \mathrm{~J}$. Mearsheimer, 'Back to the Future: Instability in Europe after the Cold War', International Security, 15(1), 1990, pp. 5-56.

${ }^{60}$ Mearsheimer, 'The False Promise', 47.

${ }^{61}$ K. N. Waltz, Theory of International Politics (Reading, MA: Addison-Wesley, 1979), p. 197.

${ }^{62}$ Sebastian Rosato, 'Europe's Troubles: Power Politics and the State of the European Project', International Security 35(4), 2011, pp. 45-86, quotation p. 59.

${ }^{63}$ Rosato, 'Europe's Troubles', p. 62.

${ }^{64}$ See Krotz, U., R. Maher, D. McCourt, A. Glencross, N. Ripsman, M. S. Sheetz, and J.-Y. Haine, 'Correspondence: Debating the Sources and Prospects of European Integration', International Security, 37(1), 2012, pp. 178-199.

${ }^{65}$ Rosato, 'Europe's Troubles', p. 47.

${ }^{66}$ On Carr's classical realist criticism of federal blueprints for Europe see D. Kenealy and K. Kostagiannis, 'Realist Visions of European Union: E. H. Carr and Integration', Millennium: Journal of International Studies, 41(2), 2013, pp. 221-246.

${ }^{67}$ E.H. Carr, Nationalism and After (London: Macmillan, 1945), at p. 53.

${ }^{68} \mathrm{~J}$. Lindley-French, 'In the Shade of Locarno? Why European Defence is Failing', International Affairs, 78(4), 2002, pp. 789-811, at p. 805. 
69. Guilhot, 'The Realist Gambit: Postwar American Political Science and the Birth of IR Theory', International Political Sociology, 2,(2), 2008, pp. 281-304, quotation p. 299.

${ }^{70} \mathrm{H}$. Morgenthau, Scientific Man Versus Power Politics (Chicago: University of Chicago Press, 1946) p. 116.

${ }^{71}$ Cited in Guilhot, 'The Realist Gambit', p. 296

${ }^{72}$ C.I Craig labels Morgenthau's discussion of world government as "speculation", Glimmer of a New Leviathan: Total War in the Realism of Niebuhr, Morgenthau, and Waltz (New York: Columbia University Press, 2003), p. 199.

${ }^{73}$ W. Scheuerman, The Realist Case for Global Reform (Cambridge: Polity Press, 2011), pp. 72-6.

${ }^{74}$ H. Morgenthau, Politics Among Nations (Chicago, Chicago University Press, 1948), p.419.

${ }_{75}^{75}$ Vaughan-Williams, 'International Relations and the "Problem of History"'.

${ }_{77}^{76}$ Elman and Elman, Bridges and Boundaries; Lawson, 'The Eternal Divide'.

${ }_{78}^{77}$ Cf. Lawson, 'The Eternal Divide?'.

${ }^{78}$ Bain, 'Are There Lessons of History', pp. 517-520. 